\title{
OBJETOS, TÉCNICAS E SUBJETIVIDADES DE FORA:A COSMOLOGIA SUL-AMERÍNDIA NO CONTATO COLONIAL DO SÉCULO XVIII
}

\author{
GUILHERME GALHEGOS FELIPPE ${ }^{1}$ \\ UNISINOS
}

\begin{abstract}
RESUMO: $O$ contato entre os grupos indígenas e os agentes coloniais no Chaco e região platina caracterizou-se por uma relação complexa e instável, constituída por momentos de aproximação pacífica e a retração hostil. Isto ocorreu, em grande medida, pelo fato de que a ontologia sul-ameríndia fundamentava-se na circulação de bens entre grupos e pessoas, tendendo à reprodução social. Pretendo demonstrar que a incorporação de objetos de fora e a aquisição de técnicas ocidentais implicaram remodelações substanciais no sistema sociológico indígena. Por isso, este conflito de cosmologias resultou em uma relação instável entre os nativos e os colonos.
\end{abstract}

PALAVRAS-CHAVE: cosmologia sul-ameríndia; circulação de bens; aquisição de técnicas.

ABSTRACT: The contact between indigenous groups and colonial agents in the Plata Basin region was marked by an unstable complex relationship, with moments of peaceful approach and hostile retraction. This was, in great part, due to the fact that the South Amerindian ontology was based on the goods' trade between individuals and groups, aiming social reproduction. This paper demonstrates that the incorporation of foreign elements and the acquisition of western techniques have involved substantial renovations in South Amerindian sociological system. Therefore, that conflict of cosmologies led to an unstable relationship between natives and Spaniards.

KEYWORDS: south Amerindian cosmology; trade in goods; acquisition of techniques.

\section{Introdução}

O convívio sistemático entre missionários, colonos e agentes administrativos com os índios que habitavam o Chaco e a região platina resultou em uma grande quantidade de relatos escritos que imprimem,

\footnotetext{
${ }^{1}$ Licenciado e Mestre em História pela PUCRS, atualmente cursando o Doutorado em História no PPGHUnisinos, sob orientação da $\operatorname{Prof}^{\mathrm{a}}$. $\operatorname{Dr}^{\mathrm{a}}$. Eliane Cristina Deckmann Fleck. E-mail: ggfelippe@yahoo.com.br.
} 
DOSSIÊ: FONTES E PROBLEMAS COLONIAIS, LEITURAS E ANÁLISES ATUAIS: TEMAS DA CULTURA SUL-AMERÍNDIA NO CONTEXTO COLONIAL

entre outras coisas, a imagem estereotipada que se fazia dos grupos nativos. Em grande parte, esta imagem criada sobre os índios é de caráter genérico, reproduzindo estereótipos cunhados desde os primeiros contatos. Explica-se assim a tão difundida inconstância indígena nos relatos coloniais que, generalizando algumas atitudes, simplificavam toda uma ontologia nativa ${ }^{2}$. Da mesma forma, configurou-se uma imagem em relação à inclinação dos índios ao trabalho e às coisas materiais. Os primeiros contatos foram sempre articulados por meio de presentes que os missionários ofereciam aos índios ou pelo convencimento, também através de artefatos, para que os caciques e seus familiares se juntassem às reduções. Estas práticas parecem ter sobrevivido aos primeiros contatos e se difundiram nas relações entre os colonos e os índios, tornando-se uma tendência descrever os nativos pela "cortedad de su capacidad y la propensión

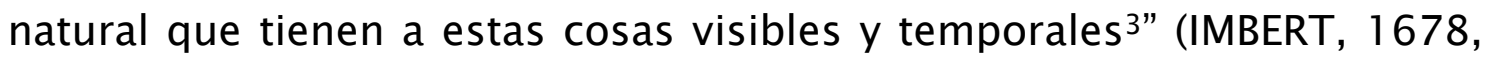
p. 1$)^{4}$.

A inclinação dos índios pelos bens materiais que os brancos poderiam providenciar passou a ser motivo de reclamação constante nos depoimentos. O que era uma estratégia para auxiliar no contato e relação com os nativos, deixou de ser providencial para se tornar uma regra, como ressalta o governador do Rio da Prata: "porque ya quieren que primero se les ponga casa, iglesia y renta antes que se empleen en el cuidado, no queriendo tener a su cargo cosa sin que antes reconozcan la conveniência5" (ROBLES, 1678, p. 8). As exigências indígenas passaram a ser a marca das negociações com os espanhóis, cabendo aos bens materiais um papel fundamental nas relações estabelecidas. O interesse dos índios parecia estar focado naqueles itens que os colonos possuíam, e, com isso, cada vez mais se consolidava o estereótipo criado pelos cronistas. O padre Pedro Guevara, por exemplo,

\footnotetext{
${ }^{2}$ Cf. Viveiros de Castro (2002a), capítulo 3.

${ }^{3}$ Carta do Bispo de Buenos Aires, Antonio Azcona e Imbert, ao governador do Rio da Prata, Don Andrés de Robles, Buenos Aires, 11 de fevereiro de 1678.

${ }^{4}$ Para facilitar a leitura, transcrevo os trechos de documentos para o espanhol moderno, assumindo, consequentemente, a inteira responsabilidade sobre a versão apresentada.

${ }^{5}$ Carta do governador do Rio da Prata, Andrés de Robles, ao Rei Carlos II, Buenos Aires, 24 de maio de 1678.
} 
DOSSIÊ: FONTES E PROBLEMAS COLONIAIS, LEITURAS E ANÁLISES ATUAIS: TEMAS DA CULTURA SUL-AMERÍNDIA NO CONTEXTO COLONIAL

é bastante objetivo neste sentido, quando descreve os Chiriguano grupo de língua guarani da região subandina - como sendo "gente infiel y nacida para urdir engaños: tan acostumbrada a la mentira, que mienten y desmienten en pocas palabras por el interés de cualquiera cosa" (GUEVARA, [1764] 1836, p. 9).

Neste sentido, é interessante observar o caso específico dos índios Pampa, que, desde meados do século XVII até a primeira metade do XVIII, sempre foram descritos como irredutíveis e não confiáveis, pois além de nunca terem fixado residência junto aos missionários, não cumpriam com os tratos feitos com os colonos. Mas o que mais tornava os Pampa um grupo peculiar era o fato de nunca terem sido arredios em relação ao mundo colonial. Muito pelo contrário, sempre mantiveram contato direto com missionários e citadinos - mesmo que nem sempre de forma pacífica. Mas o fato é que sua proximidade com os agentes coloniais foi uma constante, comprovando um grande interesse pelas coisas do mundo dos brancos. Observa-se a declaração feita em tom de desabafo pelo bispo de Buenos Aires acerca destes índios:

Es así, señor, que no ay en toda esa región nación más infiel, bárbara y obstinada que esa de los Pampas, porque jamás se ha podido en ella hacer fruto, sin embargo que es la que más comunicación tiene con la gente española y con la palabra, el ejemplo: se le predica la $\mathrm{Fe}$ muy de ordinario ni más irreducible a poblaciones y vida política, porque su fiero natural lo repugna poderosamente y sin duda, por estar en conocimiento de todo eso, con las muchas experiencias que tienen las religiones, no se movieron en aquella ocasión que refiere dicho Gobernador a ir predicar el evangelio a dichos indios y prudentemente recelaron el hacerlo porque son notables engañadores y se dejan bautizar $y$ ofrecen sus hijos para que los bauticen por algún interés temporal que esperan $y$ en consiguiéndolo ellos y sus hijos parten a las campañas y prosiguen en su gentilismo ${ }^{6}$ (IMBERT, 1683, p. 2-3, sem grifos no original).

\footnotetext{
${ }^{6}$ Carta do Bispo de Buenos Aires, Antonio Azcona e Imbert, ao Rei Carlos II, Buenos Aires, 09 de janeiro de 1683 .
} 
A reclamação gira em torno do interesse que os índios tinham em relação às coisas materiais em detrimento das questões espirituais, frequentemente colocadas em segundo plano, ou usadas de forma a alcançar estes bens. Porém, algumas décadas depois, alguns índios Pampa, espontaneamente, foram pedir proteção ao governo de Buenos Aires, pois estavam sendo hostilizados por outros grupos. É interessante notar que, no mesmo momento em que se confirma a solicitação destes índios, acrescenta-se que "en caso de ser invadidos por enemigos, se les den algunas armas y dando aviso al Gobernador se les socorra con alguna gente para su defensa?" (ANÔNIMO, 1741, p. 12). A origem desta aproximação parece estar menos ligada aos interesses espirituais ou evangélicos do que às armas e proteção que o governo portenho poderia oferecer a eles. Desta maneira, os conflitos intertribais - e de origem anterior ao contato com o mundo branco adquiriam meios para sua manutenção e potencialização, seja pelas novas alianças estabelecidas ou pela tecnologia introduzida pelos colonos, como o metal ou a montaria.

A motivação existente entre os índios em relação aos bens materiais fornecidos pelo mundo colonial 8 não deve ser analisada de forma superficial, a ponto de entendê-la como uma inclinação ao acúmulo de riquezas visando ao enriquecimento individual, que, ao que indicam as fontes, não vigorava na organização socioeconômica nativa. Por isso, compreendo o interesse e subsequente incorporação de artefatos estrangeiros às relações sul-ameríndias como parte da esfera sociológica nativa, pautada na reciprocidade, circulação de bens, reprodução do corpo social e aquisição de novas técnicas e objetos. Para analisá-los, irei recorrer à documentação produzida por diversos agentes coloniais que entraram em contato com grupos indígenas nas regiões da bacia do Rio da Prata e do Chaco durante o século XVIII, com

\footnotetext{
${ }^{7}$ Extracto sobre la nueva reducción y población de los indios infieles de la nación Pampa, 11 de agosto de 1741.

${ }^{8}$ Cabe ressaltar que, no século XVIII, materiais de ferro, animais de tração, o mercúrio, a bebida destilada ou outros artefatos importados pelos brancos já não eram novidades para muitos grupos sul-ameríndios que, em contato sistemático por décadas ou séculos, já haviam incorporado estes bens às suas práticas cotidianas. Porém, muitos destes itens ou só eram adquiridos por meio de trocas com os colonos, ou estavam sujeitos às demandas do comércio e contrabando colonial (PALERMO, 2000).
} 
DOSSIÊ: FONTES E PROBLEMAS COLONIAIS, LEITURAS E ANÁLISES ATUAIS: TEMAS DA CULTURA SUL-AMERÍNDIA NO CONTEXTO COLONIAL

destaque para relatos que possam evidenciar a maneira como os grupos indígenas gerenciaram os produtos adquiridos através do contato colonial. É necessário, no entanto, esclarecer antes alguns pontos a respeito do comportamento ontológico nativo.

Esta relação com os objetos e a maneira como eram empregados na socialidade indígena podem ser entendidas a partir do que Bruno Latour (1994) chamou de simetria entre os meios naturais e sociais para distinguir os pré-modernos dos modernos. Segundo o filósofo, os modernos regem a sua realidade de acordo com uma concepção universalista que distingue a natureza - elemento transcendente ao homem, mas "mobilizável, humanizável, socializável”(LATOUR, 1994, p. 42) - da cultura, imanente, mas também transcendente, pois, ao mesmo tempo em que é o homem quem a cria, o "ultrapassa infinitamente" (LATOUR, 1994, p. 37) ${ }^{9}$. Já para os pré-modernos, natureza e cultura "são apenas dois ramos do mesmo governo" (LATOUR, 1994, p. 36), não se estabelecendo a dicotomia entre o que é transcendente e o que é imanente, resultando numa relação intrínseca e simétrica entre o meio social e a ordem natural. Para além de uma diferença de "visões de mundo", cada uma destas concepções gera lógicas relacionais específicas, mantendo sistemas sociológicos próprios: os modernos, por exemplo, fazem a diferenciação entre os humanos e os não humanos restringindo aos primeiros a capacidade de raciocinar e, por isso, tutelar os segundos -; diferente dos pré-modernos, que mantêm amplas suas redes relacionais, estendendo o poder de agenciamento dos seres: "entidades divinas, espíritos de animais, de vegetais e espectros de mortos, homens e objetos, fazem parte de um mesmo Universo, no qual inexiste uma separação radical dos elementos" (CATAFESTO DE SOUZA, 2002, p. 241).

\footnotetext{
9 "Uma espécie de quiasma onde o pólo natureza e o pólo sociedade são ora transcendentes e ora imanentes. A natureza é transcendente no nosso imaginário (ela é externa e independente de qualquer subjetividade), mas, ao mesmo tempo, ela é imanente, pois podemos (re)criá-la artificialmente no laboratório, e, ainda por cima, em condições ideais; por outro lado, a sociedade é transcendente (ela é exterior e até se impõe aos indivíduos, diria Durkheim) e, pari passu, imanente, pois somos nós que constituímos a sociedade (o Leviatã é o resultado do cálculo pragmático dos indivíduos, diria Hobbes)" (GORDON, 2003, p. 7).
} 
DOSSIÊ: FONTES E PROBLEMAS COLONIAIS, LEITURAS E ANÁLISES ATUAIS: TEMAS DA CULTURA SUL-AMERÍNDIA NO CONTEXTO COLONIAL

Esta postura ontológica indígena implica noções e reflexões próprias sobre o meio em que vivem e sobre os elementos que constituem esta realidade. A utilização de certos instrumentos, como os ritualísticos ou de caça, por exemplo, postula apropriações conceituais que não são imanentes ao objeto,

pois as coisas não são apenas percebidas, mas são assim conhecidas, o que também equivale a dizer que são classificadas. Daí, as pessoas que percebem os mesmos objetos não estão necessariamente percebendo os mesmos tipos de coisas (SAHLINS, 2001, p. 176-177, grifos do autor).

Isto quer dizer que os conceitos são compartilhados dentro de um mesmo grupo social, e o significado e utilidade que são dados às coisas é particular àquela cosmovisão. Nesta lógica, para serem incorporados artefatos alienígenas ou adotadas novas técnicas de trabalho ao sistema socioeconômico nativo, precisam ocorrer algumas reestruturações sociais:

Indo no sentido contrário do determinismo tecnológico que freqüentemente impregna as teorias evolucionistas, poderíamos postular aqui que a transformação realizada por uma sociedade em sua base material é condicionada por uma mutação prévia das formas de organização social que servem de esqueleto ideal ao modo material de produzir (DESCOLA apud LATOUR, 1994, p. 46).

No que compete à relação entre os seres, a ontologia indígena sustenta uma semelhança antes anímica do que natural entre as diversas entidades que povoam o mundo, estabelecendo-se uma "diferença de grau, não de natureza, entre os homens, as plantas e os animais" (DESCOLA, 1998, p. 25). Esta "teoria da mente" aplicada pelo nativo (VIVEIROS DE CASTRO, 2002b, p. 130) é antagônica à ontologia naturalista, que conhece e classifica os seres em categorias essencialmente biológicas e, por isso, naturais:

O animismo pode ser definido como uma ontologia que postula o caráter social das relações entre as séries 

TEMAS DA CULTURA SUL-AMERÍNDIA NO CONTEXTO COLONIAL

humana e não-humana: o intervalo entre natureza e sociedade é ele próprio social. O naturalismo está fundado no axioma inverso: as relações entre sociedade e natureza são elas próprias naturais. Com efeito, se no modo anímico a distinção natureza/cultura é interna ao mundo social, pois humanos e animais acham-se imersos no mesmo meio sociocósmico (e neste sentido a natureza é parte de uma socialidade englobante), na ontologia naturalista a mesma distinção é interna à natureza (e neste sentido a sociedade humana é um fenômeno natural entre outros) (VIVEIROS DE CASTRO, 2002a, p. 364).

Com isso, não estou propondo qualidades perspectivas sobre a realidade. Não é minha intenção sugerir que a forma como os índios compreendem ou refletem sobre o mundo é melhor ou mais justa que a dos modernos - mesmo porque este não é o caso ${ }^{10}$. O que pretendo aqui é pensar como esta distinção de ontologias funciona na relação entre índios e brancos de maneira a não homogeneizar seus comportamentos, já que "não são as relações que variam, são as variações que relacionam" (VIVEIROS DE CASTRO, 2002b, p. 120). Parto do princípio que são duas ontologias distintas, produtoras de entendimentos opostos acerca do mundo que vivenciam.

\section{A reciprocidade como mobilizadora social}

Os diversos grupos indígenas que habitavam as regiões platina e chaquenha durante a época colonial apresentavam uma considerável variedade de práticas de subsistência, coexistindo modelos nômades, fundamentados em regime de caça e coleta, e grupos sedentários, praticantes de horticultura doméstica. Porém, no que compete à organização socioeconômica, a etnografia e os dados históricos

\footnotetext{
10 “[...] o relativismo não significa que uma cultura ou um costume sejam tão bons quanto quaisquer outros, se não melhores; trata-se, antes, da simples prescrição de que, para serem inteligíveis, as práticas e ideais de outras pessoas devem ser situadas em seu próprio contexto, compreendidos como valores posicionais num campo de suas próprias relações culturais, e não apreciados em termos de juízos intelectuais e morais fabricados por nós. O relativismo é a suspensão provisória dos nossos próprios juízos, a fim de situar as práticas em questão na ordem histórica e cultural que as tornou possíveis" (SAHLINS, 2004, p. 22).
} 
DOSSIÊ: FONTES E PROBLEMAS COLONIAIS, LEITURAS E ANÁLISES ATUAIS: TEMAS DA CULTURA SUL-AMERÍNDIA NO CONTEXTO COLONIAL

informam que estes grupos compartilhavam um sistema baseado na transmissão coletiva dos elementos extraídos do exterior ou produzidos pelo grupo entre os seus membros, fazendo com que o econômico não fosse "um setor com desenvolvimento autônomo no campo social" (CATAFESTO DE SOUZA, 2002, p. 222):

A exogamia lingüística e a rede de circulação dos artefatos geram uma situação na qual cada tribo, cada grupo local, se percebe como um elemento no seio de um metassistema regional, elemento que deve sua perenidade material e ideal às trocas regradas com as outras partes do todo (DESCOLA, 1998, p. 38).

Diferente da ontologia ocidental, que visa ao enriquecimento por meio da apropriação de bens, almejando a intensificação das distinções sociais, a ontologia sul-ameríndia busca a repartição dos elementos em um sistema de redistribuição. Assim, "as estratégias do princípio de reciprocidade, responsáveis pela coesão aldeã, levam a que os recursos produzidos globalmente sejam distribuídos de forma equilibrada entre as diferentes famílias" (CATAFESTO DE SOUZA, 2002, p. 233).

Neste sentido, a reciprocidade seria um "valor cardinal" (DESCOLA, 1998, p. 30) que articula não só as relações e o crescimento social do grupo interno, mas também gerencia o que é externo à esfera reciprocitária. Dito de outra forma, as trocas generalizadas funcionavam como uma dobradiça sociológica que regulava a geometria virtual do grupo, colocando os aliados dentro do regime de consumo dos bens materiais e simbólicos extraídos na esfera externa:

Tratava-se, em suma, de uma ordem onde o interior e a identidade estavam hierarquicamente subordinados à exterioridade e a diferença, onde o devir e a relação prevaleciam sobre o ser e a substância. Para esse tipo de cosmologia, os outros são uma solução, antes de serem - como foram os invasores europeus - um problema (VIVEIROS DE CASTRO, 2002a, p. 220-221).

Buscava-se, com isto, a renovação de substâncias individuais e coletivas, gerada pela absorção dos elementos estrangeiros. A circulação dos bens coletados, distribuídos, trocados ou presenteados 

TEMAS DA CULTURA SUL-AMERÍNDIA NO CONTEXTO COLONIAL

entre os membros era a forma sistemática de alcançar a reprodução interna do grupo, que, como um ens incompletum, não era capaz de se autorreproduzir isoladamente (FAUSTO, 1999, p. 265-266). Isto explica, por exemplo, o ritual antropofágico, em que se incorporava, literalmente, o inimigo em uma cerimônia canibal ou, após sua morte e esquartejamento no campo batalha, suas partes eram distribuídas como presentes entre os membros do grupo vencedor. O padre Pedro Guevara afirma que as velhas tinham "el privilegio de arrancar los dientes y muelas de los difuntos para ensartarlos en testimonio de su valentia", e as moças só teriam a permissão matrimonial "probando primero la sangre de sus enemigos" (GUEVARA, [1764] 1836, p. 13 e 16) ${ }^{11}$; ou, ainda, cortava-se a cabeça das vítimas "y la llevaban por trofeo enristrada en las puntas de las lanzas" (GUEVARA, [1764] 1836, p. 13 e 16) ${ }^{12}$. Tomava-se do "outro aquilo que ele tem de outro" (GORDON, 2006, s/p.):

Trata-se de economias que produzem pessoas e não objetos, que concebem a relação com o exterior como sendo necessária à reprodução interna e que se articulam com esse exterior primariamente por meio da predação. Ou, dito de outro modo, temos economias que predam e se apropriam de algo fora dos limites do grupo para produzir pessoas dentro dele. Sugiro que essa apropriação violenta, predatória e guerreira não deve ser pensada como uma forma de troca, mas sim como consumo produtivo, um conceito que retiro de Marx (FAUSTO, 1999, p. 266-267).

O conceito de "consumo produtivo" é bastante explicativo, na medida em que determina que as substâncias extraídas da esfera

\footnotetext{
${ }^{11}$ Guevara completa ressaltando que "los Guaranís, que también eran antropófagos, no permitían a sus hijas tomar estado, hasta que les acudiesen la primera vez sus reglas" (GUEVARA, [1764] 1836, p. 16). Ao que parece, a ingestão de sangue do inimigo era uma forma de reposição da substância perdida na menstruação. Assim, o sangue do inimigo permitia a continuidade reprodutora do grupo, na medida em que a transferência de substâncias possibilitava o ritual de passagem das moças, num mecanismo de construção corporal - o sangue reposto no lugar do sangue descartado.

12 cf. também Lozano (1733, § X, fls. 71, 79) e Anônimo ([out./1735], fl. 5v). Em relação ao livro de Pedro Lozano, utilizo aqui a versão impressa em 1733, apesar de existir uma edição recente, com as devidas correções para o espanhol moderno. Para facilitar a busca tanto no original como na edição moderna, referencio o capítulo no qual o trecho foi coletado, visto que em ambas as edições a numeração capitular mantêm-se idêntica.
} 
DOSSIÊ: FONTES E PROBLEMAS COLONIAIS, LEITURAS E ANÁLISES ATUAIS: TEMAS DA CULTURA SUL-AMERÍNDIA NO CONTEXTO COLONIAL

externa devem ser absorvidas no e pelo grupo, a fim de mobilizá-lo, sem a necessidade de uma reparação obrigatória ou voluntária, já que, em algum momento futuro, aquela esfera externa, agora sob a perspectiva inversa, irá cobrar reparação naquilo que é o seu exterior. Nesta lógica indígena, como pontua Carlos Fausto (1999), não há trocas, mas sim predação de ambas as partes. Porém - e o que eu gostaria de aprofundar aqui -, uma vez dentro do grupo, estes elementos exteriores tinham algumas funcionalidades, podendo ser imediatamente absorvidas em rituais, servirem como dádivas numa lógica do dom, ou serem usadas como bens de troca, de forma a criar uma rede de circulação de objetos. No final das contas, este sistema operava em uma lógica de antiacúmulo, justamente porque visava à mobilidade qualitativa do coletivo, e não a valorização quantitativa do indivíduo. $O$ próprio papel da liderança indígena (genericamente chamada de cacique) era fundamentado na capacidade deste sujeito de distribuir bens a todos seus seguidores. Ao contrário de ser um captador de recursos para si, o cacique era um capitalizador de relações, conquistadas a partir de sua "capacidad para la gestión de la fiesta y la guerra" (WILDE, 2003, p. 222). Por isso, independente da maneira como se alcançava tal função no grupo, o líder ocupava mais um cargo de prestígio do que coerção ou policiamento. Ao consultarmos os relatos históricos, constataremos que os missionários, ou agentes administrativos, perceberam isso desde cedo, fundamentando suas relações de contato com os grupos nativos sempre por intermédio dos chefes de família ou das aldeias. A sua produção ou coleta de objetos deveria ser a mais bem sucedida de todos, pois este era o cerne de sua função: "o cacique deve redistribuir bens em muito maior número do que os que recebe" (KERN, 1985, p. 34). Exemplo disso é um ocorrido no início de 1769, em que um cacique foi ao encontro de Francisco Bruno de Zavala, em meio a conversações sobre a redução dos índios Minuano, para "ver lo que le daba y apurándole por su resolución a hacerse cristiano, [dije] que iría a sus toldos y que lo vería13" (ZAVALA,

\footnotetext{
${ }^{13}$ Carta de Francisco Bruno de Zavala ao governador do Rio da Prata, Don Francisco de Bucarelli, Yapeyu, 9 de fevereiro de 1769.
} 
DOSSIÊ: FONTES E PROBLEMAS COLONIAIS, LEITURAS E ANÁLISES ATUAIS: TEMAS DA CULTURA SUL-AMERÍNDIA NO CONTEXTO COLONIAL

1769, f. 1). Mais importante do que a negociação com o funcionário do governo platino, o cacique tinha responsabilidade para com aqueles que o seguiam e que viam nele a figura mais adequada para fazer circular os bens.

Em outra ocasião, décadas antes, um grupo de índios pampeanos invadiu e assaltou um rancho, fugindo com ornamentos da igreja após matar e raptar algumas pessoas. No dia seguinte, ficou-se sabendo que índios Charrua haviam atacado a aldeia dos invasores, tomando para si os cativos que haviam sido levados no dia anterior. Sabendo disso, o governador do Rio da Prata resolveu negociar com estes índios:

Mandé pasar a esta banda a los cacique principales de estos Charrúas y les agradecí la acción que habían hecho en defensa del español, dándoles camisetas, espuelas $y$ frenos $y$ volvieron muy contentos, ofreciéndome tendrían junta la chusma que habían cogido por esclavos de los dichos Serranos y Pampas ${ }^{14}$ (HERRERA, 1686, p. 4).

As trocas estabelecidas entre o governador e os caciques ocorreram devido ao auxílio que os Charrua haviam prestado aos colonos, configurando assim uma circulação bilateral: aos caciques foram dados objetos ligados à cavalaria, que provavelmente seriam repassados aos demais nativos do grupo, bem como as vestimentas; em contrapartida, as pessoas raptadas voltaram aos seus locais de origem. Para ambos, esta troca formalizava o estabelecimento de uma aliança importante, tendo em vista a situação de constante conflito com grupos indígenas da região. Porém, para os índios, oferecer os cativos de guerra implicava uma relação mais complexa, baseada na circulação de pessoas.

As denúncias de grupos indígenas invadindo e assaltando estâncias e povoados ao longo do século XVIII são muito frequentes na documentação. Além do furto de grandes quantidades de animais, estas invasões resultavam em morte e rapto de pessoas. Exemplo disto são as frequentes invasões iniciadas na década de 1730 pelos Paiaguá - grupo

\footnotetext{
${ }^{14}$ Carta do governador do Rio da Prata, Don José de Herrera, ao Rei da Espanha, Buenos Aires, 05 de dezembro de 1686
} 
DOSSIÊ: FONTES E PROBLEMAS COLONIAIS, LEITURAS E ANÁLISES ATUAIS: TEMAS DA CULTURA SUL-AMERÍNDIA NO CONTEXTO COLONIAL

chaquenho pertencente ao tronco linguístico Guaicuru - às missões de índios Guarani, que resultaram na morte de cerca de noventa pessoas e na captura de outras sessenta, principalmente mulheres e crianças (CA, 1730-1735, p. 407). As denúncias também recaíam sobre a sucessão de assaltos que índios Mocovi realizaram ao longo de 10 anos às estâncias das reduções jesuíticas, como São Inácio, São José e Santiago. De janeiro de 1748 até dezembro de 1757, contabilizaram-se os furtos de milhares de animais (entre os quais cavalos, mulas, vacas e bois), a morte de dezenas de pessoas e raptos de catorze crianças e um homem (TATA, 1758, n. 23) ${ }^{15}$. Independente do exagero dos números, o que eles demonstram é a continuidade na prática da captura de cativos de guerra. Genericamente, estes raptos estão relacionados aos cerimoniais de antropofagia, ligados às festas e convites entre as aldeias aliadas. Porém, esta não era a única finalidade dada aos cativos: muitos grupos sul-ameríndios utilizavam-nos como bens de troca em redes de comercialização ou para a sua incorporação no seio familiar. Analisarei primeiro a questão das trocas e comercialização dos cativos.

\section{Aquisição e circulação de objetos por meio da comercialização}

Em 1684, o Conselho das Índias ficou incumbido de fazer uma representação formal à expedição do Procurador da Companhia de Jesus, Diego Altamirano, das terras que vão de Buenos Aires até o Estreito de Magalhães, a fim de fundar missões junto aos índios ali presentes. Ainda no início do documento, comenta-se a existência de espanhóis que poderiam servir de interlocutores aos nativos da região, já que "apresados de los enemigos Araucanos en las guerras de Chile pasando de una nación en otra, han llegado a Buenos Aires 16" (CONSELHO DAS ÍNDIAS, 1684, p. 2). A mobilidade destes cativos de um grupo para o outro está inserida num contexto colonial mais amplo de paz e guerra entre índios e colonos. Esta vasta região pampeana, que se

\footnotetext{
${ }^{15}$ Carta do corregedor do cabildo de Santiago, Don Luis Tata, ao governador do Rio da Prata, Pedro de Ceballos, Santiago, 26 de fevereiro de 1758.

${ }^{16}$ Carta do Conselho das Índias ao Rei da Espanha. 12 de maio de 1684.
} 
DOSSIÊ: FONTES E PROBLEMAS COLONIAIS, LEITURAS E ANÁLISES ATUAIS: TEMAS DA CULTURA SUL-AMERÍNDIA NO CONTEXTO COLONIAL

estendia do Rio Paraná até as cordilheiras, era habitada por um semnúmero de grupos indígenas e estava sendo ocupada pelo Estado colonial através de missões religiosas e vacarias. Miguel Palermo comenta sobre o contrabando realizado pelos índios nesta região:

En el siglo XVII se inició una época de paz en Chile y el comercio fluyó más libremente, posibilitándose el acceso de muchos grupos a los mercados coloniales, donde además de producción textil y otras cosas ofrecían también ganado de las pampas trascordilleranas, cimarrón o tomado a las estancias pampeanas. De esa manera, quienes al este de la cordillera eran para los blancos peligrosos enemigos, podían ser pacíficos vendedores al otro lado de los Andes (PALERMO, 2000, p. 374).

A paz vivenciada no Chile oportunizava a venda de animais roubados em ataques e guerras nas cidades e estâncias do Rio Paraná e Uruguai, como denuncia o governador do Rio da Prata: "los Serranos suelen darse la mano con los Aucas de Chile a quienes venden las caballadas y los robos que aquí hacen17" (HERRERA, 1686, p. 4). Este comércio ilegal efetuado na região pampeana pode ser pensado como um dos meios de os inimigos apresados em regiões distantes serem comercializados por toda esta região, em troca de bens consumíveis.

O comércio, consequentemente, pode ser visto como outra forma de os índios conseguirem ter acesso aos artefatos que thes interessavam. Porém, grande parte destes acordos comerciais não estava regulamentada pelas diretrizes coloniais, ficando à margem das regras e administração dos agentes autorizados. Com isso, os colonos, "a causa de las fraudes y engaños con que tratan a los indios en sus comercios, y por sus escandalosas operaciones 18" (CÉDULA REAL, 1727, f. 1), beneficiavam-se substancialmente. Porém, isto não diminuía os trâmites comerciais entre índios e colonos que, apesar das inúmeras denúncias feitas, continuavam existindo. Em carta dirigida ao vice-Rei, o cacique abipone Miguel Benavides demonstra-se a favor da manutenção

\footnotetext{
${ }^{17}$ Carta do governador do Rio da Prata, Don José de Herrera, ao Rei da Espanha, Buenos Aires, 05 de dezembro de 1686.

${ }^{18}$ Cédula Real ao Padre Superior das Missões de Chiquitos, 06 de julho de 1727.
} 
DOSSIÊ: FONTES E PROBLEMAS COLONIAIS, LEITURAS E ANÁLISES ATUAIS: TEMAS DA CULTURA SUL-AMERÍNDIA NO CONTEXTO COLONIAL

do comércio entre os indígenas e os espanhóis. O maior problema apontado pelo cacique era a existência de uma tutela por parte dos administradores dos povoados, que estariam intermediando os tratos, enquanto os Abipone eram capazes de realizar estas negociações por si mesmos, acrescentando que "aun cuando sea capaz de engañarnos en el contrato el español mercader, sufriríamos con gusto el engaño primero que la violencia del administrador y protector 19" (BENAVIDES, c. 1780, f. 7).

O fato é que, com ou sem fiscalização governamental, os índios mantinham suas compras e vendas; geralmente trocando, com os espanhóis, bens furtados em estâncias, povoados ou cidades por itens ligados ao seu cotidiano. Os índios Pampa, por exemplo, caçavam éguas que encontravam pelos campos e trocavam-nas por ponchos com os Mapuche, ou trocavam com os espanhóis laços feitos de couro destas por aguardente (CA, 1735-1743, p. 581-582).

$\mathrm{O}$ alcaide da cidade de Santa Fe denuncia uma rede clandestina de trocas entre os índios Mocovi de São Xavier e colonos, em que eram os próprios espanhóis que iam "a compra de cueros a cambio de géneros y de aguardiente furtivamente de modo que resulta de esto toda la ruina de los Pueblos, porque por naturaleza son propensos a la embriagues20" (LASSAGA, 1785, f. 7). Além do problema da embriaguez, vista como um empecilho à empresa civilizatória, tal situação esclarece as razões dos constantes assaltos a estâncias realizados pelos nativos. Neste caso específico, o couro em poder dos Mocovi era proveniente de ações furtivas que resultavam no roubo de gado das estâncias do povoado de São Jerônimo, como já havia sido denunciado por Miguel Benavides (c. 1780, f. 2-3v).

As complicações provenientes destes comércios já eram constatadas há muito tempo, a ponto de o governador do Rio da Prata emitir normas de proibição à venda de armas e bebidas alcoólicas aos índios que frequentavam a cidade de Buenos Aires (ROZAS, 1742, f. 14-

\footnotetext{
${ }^{19}$ Carta do cacique Don Miguel Gerónimo Benavides ao Vice-rei Don Juan José de Vértiz y Salcedo, São Jerônimo, cerca de 1780 .

${ }^{20}$ Informe do alcaide Don Gabriel de Lassaga ao governador intendente de Buenos Aires Francisco de Paula Sanz, Santa Fe, 06 de outubro de 1785.
} 
DOSSIÊ: FONTES E PROBLEMAS COLONIAIS, LEITURAS E ANÁLISES ATUAIS: TEMAS DA CULTURA SUL-AMERÍNDIA NO CONTEXTO COLONIAL

$14 \mathrm{v})^{21}$. A prática comercial parece ter sido uma modalidade satisfatoriamente introduzida nos meios nativos de captação de recursos, mas destituída da acumulação presente no pensamento ocidental. A ganância e a usura, ao que tudo indica, não faziam parte das permutas que os nativos realizavam entre si e com os espanhóis. A lógica não se pautava na retirada de elementos de uma esfera de modo a armazená-los em outro meio, atribuindo a eles um valor perene e anterior à sua utilidade. Porém, isto não significa acreditar que o regime nativo de circulação de bens possuía intrinsecamente um caráter humanitário que visava exterminar qualquer possibilidade de empobrecimento alheio. Se houvesse a possibilidade de empobrecimento, haveria consequentemente a existência de enriquecimento e, por conseguinte, a diferenciação de níveis gradativos de posse e propriedade 22 . Gonzalo de Doblas é bastante enfático ao tratar a postura que os Guarani mantinham frente ao senso de pertencimento: "es patente a todo el mundo que los bienes de comunidad no los miran los individuos que la componen como propios, sino para disiparlos, porque les falta la propiedad en particular" (DOBLAS, [1785] 1836, p. 34). Esta falta de senso de propriedade, a qual se refere o funcionário real, era um dos motivos que levaram as autoridades a duvidarem da eficácia do trabalho indígena. Por isso, para os agentes coloniais, os índios não eram bons na administração dos meios produtivos, pois somente na aparência "alegan otro que parece honesto como es la comodidad de sembrar y criar sus ganados23" (IMBERT, 1678, p. 4).

Ao discernimento ocidental era inaceitável a falta de previsão para as coisas futuras que os indígenas aparentavam ter:

\footnotetext{
${ }^{21}$ Bando do governador do Rio da Prata, Domingo Ortiz Rozas, Buenos Aires, 27 de outubro de 1742.

22 "Os povos mais primitivos do mundo têm poucas posses, mas não são pobres. A pobreza não consiste em uma determinada quantidade reduzida de bens, nem é apenas uma relação entre meios e fins; acima de tudo, é uma relação entre pessoas. A pobreza é um status social. Como tal, é uma invenção da civilização. Cresceu com a civilização, imediatamente como uma distinção odiosa entre as classes e, o que é mais importante, como uma relação tributária - capaz de tornar os camponeses agricultores mais suscetíveis às catástrofes naturais do que qualquer acampamento hibernal de esquimós do Alasca" (SAHLINS, 2004, p. 146, grifos do autor).

${ }^{23}$ Carta do Bispo de Buenos Aires, Antonio Azcona e Imbert, ao governador do Rio da Prata, Don Andrés de Robles. Buenos Aires, 11 de fevereiro de 1678.
} 
DOSSIÊ: FONTES E PROBLEMAS COLONIAIS, LEITURAS E ANÁLISES ATUAIS: TEMAS DA CULTURA SUL-AMERÍNDIA NO CONTEXTO COLONIAL

Agregue vd. a esto las ideas tan bajas que tienen de sí mismos, el poco conocimiento de la vida acomodada de los que poseen bienes, y de las distinciones y honras que estos logran entre los demás hombres, y el no tener ambición de dejar a sus hijos herencia después de su muerte [...] (DOBLAS, [1785] 1836, p. 32).

A inexistência de herança nas relações familiares nativas é compreensível se ela for entendida como a transmissão sucessiva de bens, cuja função última é a perpetuação de um patrimônio alienável. Além da concepção de acúmulo, a prática da herança necessita da valorização dos bens enquanto artefatos possuidores de um valor intrínseco e superior à coisa em si. Já o sentido e utilidade que os nativos empregavam aos objetos eram estruturalmente diferentes daqueles que os espanhóis atribuíam:

a representação de um mundo repleto de entidades espirituais (o que se denominou animismo) faz com que nenhum bem material seja visto somente pela sua utilidade, mas também pela rede de relações místicas que permitiram o seu aparecimento (CATAFESTO DE SOUZA, 2002, p. 241).

Neste sentido, pensar que as coisas têm dono é um contrassenso ao sistema socioeconômico indígena. Um índio "da todo sin concierto al primero que se lo pide si está en su mano24" (NUSDORFFER, 1738, f. 15), porque esta é a função dos objetos: gerar relações, permitir que as pessoas se comuniquem e troquem elementos, gastando toda potência energética que os artefatos podem oferecer. O resultado disso é a dádiva, e consequente dívida, que dá propulsão ao socius indígena. Na ontologia sul-ameríndia, crime não é roubar; crime é não dar (VIVEIROS DE CASTRO, 2009, p. 90).

\section{A questão das novas técnicas}

\footnotetext{
${ }^{24}$ Información y certificación acerca de varios puntos pertenecientes a los indios guaraníes, mandadas hacer por el P. Jayme de Aguilar, provincial de las Provincias del Paraguay, Tucumán y Río de la Plata. Assinado pelo padre Bernardo Nusdorffer, Santa Candelaria, 15 de marzo de 1738.
} 
DOSSIÊ: FONTES E PROBLEMAS COLONIAIS, LEITURAS E ANÁLISES ATUAIS: TEMAS DA CULTURA SUL-AMERÍNDIA NO CONTEXTO COLONIAL

Retomando a divisão ontológica que Bruno Latour (1994) propôs entre os modernos e os pré-modernos, há, ainda, que se analisar a questão da aquisição de novas técnicas nos meios socioeconômicos. A ideia inicial parte da suposição que toda inovação metodológica ou instrumental resulta em um crescimento produtivo e consequente aprimoramento social25. Porém, Latour salienta que, para os modernos, esta incorporação tecnológica é facilitada devido à divisão entre a sociedade e a natureza - o dualismo inescapável dos modernos, "os humanos de um lado, os não-humanos de outro, os signos de um lado, as coisas de outro" (LATOUR, 1994, p. 100). Desta forma, os modernos privilegiam ampliações materiais sem se importar com as consequências geradas à ordem social (LATOUR, 1994, p. 44-45). Já para os prémodernos, as multiplicações culturais implicam obrigatoriamente transformações naturais na sua composição sociocosmológica:

É a impossibilidade de mudar a ordem social sem modificar a ordem natural - e inversamente - que obriga os pré-modernos, desde sempre, a ter uma grande prudência. Todo monstro torna-se visível e pensável e expõe explicitamente graves problemas para a ordem social, o cosmos ou as leis divinas (LATOUR, 1994, p. 46).

Dito de outra forma, a introdução de objetos ou conceitos alienígenas só é possível, para os selvagens, quando há uma reconfiguração na sua estrutura espiritual. Se, para os modernos, a "amplitude da mobilização é diretamente proporcional à impossibilidade de pensar diretamente suas relações com a ordem social" (LATOUR, 1994, p. 47, sem grifo no original), para os pré-modernos ela é inversamente proporcional: "la novedad no debía chocar con valores muy centrales de la sociedad" (PALERMO, 2000, p. 346).

As expectativas dos agentes coloniais giravam em torno da incorporação dos índios nos meios de produção coloniais,

\footnotetext{
${ }^{25}$ Assim é, por exemplo, com a passagem da economia paleolítica para a revolução agrícola do Neolítico, acreditando-se que o homem adquiriu capacitações técnicas que o possibilitaram sair de uma condição de recursos insuficientes em um regime de subsistência para a fartura e o ócio produtivo da domesticação de plantas e animais (SAHLINS, 2004).
} 
DOSSIÊ: FONTES E PROBLEMAS COLONIAIS, LEITURAS E ANÁLISES ATUAIS: TEMAS DA CULTURA SUL-AMERÍNDIA NO CONTEXTO COLONIAL

principalmente no que compete à agropecuária. Seja nos povoados indígenas tutelados por missionários ou no sistema de encomienda, a utilização da mão de obra nativa era intensa e dependente da capacidade dos índios de produzirem para o mercado colonial. Porém, grande parte dos grupos indígenas que mantinham contato com os espanhóis eram vistos como incapacitados para tal ofício. Missionários, encomenderos e colonos em geral concordavam que a indolência e a despreocupação em guardar provisões para o futuro eram dificuldades recorrentes quando se tratava do trabalho indígena na terra.

A adaptabilidade indígena ao método produtivo colonial parece ter sofrido empecilhos justamente porque a agricultura autóctone, quando realizada por alguns grupos nativos, era geralmente feita em escala doméstica, baseada na divisão por sexo do trabalho, com recursos limitados e sob o regime de prodigalidade ${ }^{26}$. Gonzalo de Doblas descreve os Guaianá - uma subdivisão dos Guarani - como índios que "siembran algunas chacras pero no las cultivan: lo que hacen es derramar la semilla en algún paraje, y al tiempo que ya les parece tendrá fruto, vuelven por allí, y recogen lo que hallan" (DOBLAS, [1785] 1836, p. 51-52).

Dentro da expectativa destes grupos, a horticultura era um complemento importante no regime alimentar, que ainda contava com a caça, coleta e pesca, resultando em uma produtividade que não ia além daquela consumida pelo grupo. Na visão dos brancos, essa economia tradicional, além de não ser suficiente para as metas de uma economia que buscava o excedente produtivo, utilizava recursos técnicoinstrumentais muito precários que deveriam ser aprimorados. E os problemas começavam justamente aí, pelo menos para os espanhóis. Os índios, mesmo os que já mantinham uma economia horticultora, pareciam não incluir em seu expediente produtivo todas as inovações que missionários e colonos tinham a oferecer. Isso não significa dizer que qualquer incorporação tecnológica com a finalidade de aumentar a produtividade tenha sido negada - deve-se recordar os instrumentos de ferro presenteados pelos brancos e que foram prontamente adotados

\footnotetext{
${ }^{26}$ Cf. Catafesto de Souza (2002), para os Guarani.
} 
DOSSIÊ: FONTES E PROBLEMAS COLONIAIS, LEITURAS E ANÁLISES ATUAIS: TEMAS DA CULTURA SUL-AMERÍNDIA NO CONTEXTO COLONIAL

pelos índios. Não se pode negar, também, que algumas reduções jesuíticas foram muito produtivas ao longo de décadas. Porém, ainda no século XVIII, as reclamações acerca do trabalho indígena centravam-se na falta de disciplina e de excedente produtivo:

Como la experiencia dio a conocer la incapacidad de los indios, y su propensión a gastarlo todo y no trabajar, fue preciso que las providencias del gobierno ampliasen las facultades a los administradores: subordinándoles en cierto modo a los corregidores y cabildos, para que así obligasen a los demás indios al trabajo y moderasen los gastos (DOBLAS, [1785] 1836, p. 21).

Há também o caso de uma queixa que o cabildo de São Inácio fez sobre os nativos, alegando sua indisposição com relação à produção do povoado, afirmando que ao invés de trabalhar, eles só queriam

andar haraganeando en dichos días y paseándose por los demás Pueblos inmediatos [...] y cuando los reprehendemos por no querer trabajar, luego cogen su camino y se van a el Paraguay sin más motivo que él no quererse sujetar a el trabajo ${ }^{27}$ (CABILDO DE SÃO INÁCIO, 1774, p. única).

A coerção física, como se sabe, não foi um meio eficiente de persuasão dos índios ao trabalho. Mas aqui a questão era antes cultural do que simplesmente preguiça ou falta de empenho.

O ritmo de trabalho ao qual os nativos estavam acostumados estava diretamente relacionado não só com o consumo do grupo, como também à possibilidade de ter tempo livre para se dedicar às práticas cerimoniais, às festividades e ao ócio. $O$ regime reciprocitário dependia ao mesmo tempo de uma produtividade satisfatória e momentos de confraternização para que estes bens circulassem. Daí que peixes, carne de caça, frutas coletadas e itens produzidos nas hortas, como ervamate, batata e milho ou mandioca - estes últimos principalmente ligados à produção de bebida alcoólica -, eram indispensáveis não só ao fornecimento de energia, mas também à disponibilização de um regime

\footnotetext{
${ }^{27}$ Carta do cabildo de São Inácio Guazú ao administrador geral das missões, Don Juan Angel de Lazcano, San Ignácio, 13 de junho de 1774.
} 
DOSSIÊ: FONTES E PROBLEMAS COLONIAIS, LEITURAS E ANÁLISES ATUAIS: TEMAS DA CULTURA SUL-AMERÍNDIA NO CONTEXTO COLONIAL

de prestações e contraprestações. Diferente do ritmo de trabalho que queriam impor os espanhóis, o cotidiano dos índios não podia se resumir integralmente à produção de alimento. Ou como bem colocou Arno Kern, "ao contrário de nossa economia, os grupos indígenas produzem para viver, mas não vivem para produzir" (KERN, 1985, p. 32).

A displicência e "horror que tiene al trabajo28" (NUSDORFFER, 1738, f. 14v) eram imagens que se mantinham sobre índios, que, na realidade, estavam mais preocupados com o que comer do que com como produzir alimento. Isto não significa que eram imprevidentes no que compete ao trabalho ou esforço físico, como supunham os espanhóis. Situações de escassez e fome não foram novidades trazidas nas caravelas europeias. É de se imaginar que os grupos sul-ameríndios já estavam acostumados a épocas de extrema carência, bem como de fartura alimentar, e a possibilidade de vivenciar cada uma delas dependia de fenômenos muito mais complexos do que aqueles decorrentes da preguiça ou da previdente dedicação ${ }^{29}$. Se há alguma novidade que os invasores trouxeram consigo foi o sentimento crônico de insatisfação, que tentaram a todo custo implantar no sistema socioeconômico nativo.

Em uma Carta Ânua há o relato sobre o regresso de quatro mil índios da milícia guarani que haviam atacado a Colônia do Sacramento dos portugueses. Ao chegarem a suas reduções, não havia o que comer, "ya que en su ausencia nadie cultivaba los campos, y la pequeña siembra que habían hecho antes de marcharse, poco correspondió a su trabajo por la sequía de aquel año" (CA, 1735-1743, p. 401). O relato continua com a descrição dos índios atacando estâncias vizinhas para aproveitar o gado "a gusto de su sustento". O que se pode evidenciar neste caso é que, além da não dedicação integral ao trabalho na terra, os índios continuavam a não estocar alimento, ou melhor, os índios

\footnotetext{
${ }^{28}$ Información y certificación acerca de varios puntos pertenecientes a los indios guaraníes, mandadas hacer por el P. Jayme de Aguilar, provincial de las Provincias del Paraguay, Tucumán y Río de la Plata. Assinado pelo padre Bernardo Nusdorffer. Santa Candelaria, 15 de marzo de 1738.

29 "Profundamente imersos no contínuo e cíclico mecanismo natural de maturação dos recursos, as sociedades Guarani tinham um ritmo variável segundo a sequiência das estações do ano. Assim como na natureza, momentos de crescimento, desenvolvimento e abundância são sucedidos por momentos de declínio e dificuldades, as sociedades Guarani não apresentavam nenhuma razão para negar este processo cíclico, e o seguiam à risca" (CATAFESTO DE SOUZA, 2002, p. 241-242).
} 
DOSSIÊ: FONTES E PROBLEMAS COLONIAIS, LEITURAS E ANÁLISES ATUAIS: TEMAS DA CULTURA SUL-AMERÍNDIA NO CONTEXTO COLONIAL

continuavam a não produzir excedentes. Esta é uma das principais reclamações que missionários e colonos tinham a respeito dos nativos. Mesmo em épocas em que estavam previstas crises produtivas, os índios consumiam - em verdadeiros banquetes - tudo o que podiam, sem armazenar nada, como descreve o jesuíta Bernardo Nusdorffer sobre os Guarani, que "lo que recoge de su sementera [...] lo consume, no reservando nada ni para las sementeras suyas del año que se sigue ${ }^{30}$ " (NUSDORFFER, 1738, f. 15); ou também o padre Miguel de Benavides, quando sugere não deixar uma cria de gado inteira aos índios Calchaqui, "porque de darles las 100 bacas todas juntas las acabarán en cuatro dias31" (BENAVIDES, 1730, f. 1).

A formação de excedente produtivo e a consequente estocagem não são apenas técnicas formalmente apreensíveis; como se os grupos humanos que não dispusessem destas práticas tivessem que passar por um processo evolutivo de aprimoramento do seu sistema produtivo. Para os grupos cuja produção se limitava a um consumo doméstico de economia tradicional, a incorporação destes expedientes implicaria modificações radicais no meio de produção, de consumo e na organização social, além de reconfigurações no âmbito cosmológico, tendo em vista que a prática de armazenamento prefigura uma mentalidade de prevenção à escassez. Assim, não só a prodigalidade ligada ao sistema reciprocitário viria a sofrer transformações, mas também aquilo que Sahlins chamou de "confiança econômica" (2004, p. 139)32; ou seja, a convicção de que os estoques alimentares disponíveis

\footnotetext{
${ }^{30}$ Información y certificación acerca de varios puntos pertenecientes a los indios guaraníes, mandadas hacer por el P. Jayme de Aguilar, provincial de las Provincias del Paraguay, Tucumán y Río de la Plata. Assinado pelo padre Bernardo Nusdorffer, Santa Candelaria, 15 de marzo de 1738.

${ }^{31}$ Carta do Padre Miguel de Benavides, São Miguel, 2 de junho de 1730.

${ }^{32}$ É bom salientar que Sahlins (2004), em seu artigo originalmente publicado em 1972, tem como linha de corte para sua análise as economias do Paleolítico e do Neolítico, afirmando que a primeira, ao contrário do que sugere o senso comum, é uma economia formadora de sociedades afluentes, cujos recursos limitados suprem satisfatoriamente as necessidades do grupo, justamente porque seus desejos e vontades não são inatingíveis, como ocorre às sociedades neolíticas, onde as "necessidades são infinitas" (id, ibid., p. 147). Porém, Sahlins parece pontuar esta distinção não tanto pelo fato de uma sociedade ser paleolítica ou neolítica, mas sim o que a organização socioeconômica do grupo privilegia nas suas relações produtivas. Por isso utilizo a análise de Sahlins para os casos sul-ameríndios, já que os dados históricos evidenciam que mesmo os grupos semissedentátios cultivadores não apresentavam uma postura rigidamente neolítica. Para este entendimento, parto das observações de Descola (2002, p. 100) ao afirmar que a domesticação de plantas não resultaria necessariamente na "estratificação social, do crescimento demográfico e da exploração do outro". O autor baseia-se em grupos norte-ameríndios exclusivamente
} 
DOSSIÊ: FONTES E PROBLEMAS COLONIAIS, LEITURAS E ANÁLISES ATUAIS: TEMAS DA CULTURA SUL-AMERÍNDIA NO CONTEXTO COLONIAL

na natureza são suficientes para suprir as necessidades de bem-estar do grupo - não apenas em uma subsistência limitada. Por isso que a aquisição de novas técnicas não implicava apenas transformações de ordem prático-instrumental - aquelas ligadas à introdução de novas ferramentas ou operações mecânicas que visassem ao crescimento produtivo -; talvez o maior problema fosse a provável modificação que traria para a ordem sociocosmológica, com desdobramentos na domesticação de animais.

De acordo com os relatos históricos, o pastoreio não era uma prática usual entre os grupos sul-ameríndios. Mesmo os horticultores reduzidos e mantidos sob a tutela jesuítica apresentavam resistência à domesticação de animais, descuidando geralmente dos animais no cativeiro ou, como já demonstrado em alguns exemplos, matando um grande número de cabeças de uma só vez. O padre Bernardo Nusdorffer descreve a situação:

Compran algunos de ellos un caballo o jumentillo si lo hallan, conservándolo o de que de una semana que lo tengan cansados ya de cuidarlo, lo dejan ir o lo dejan atado sin soltarlo al pasto, ni quitarle los lomillos hasta que se muere de hambre o de mataduras. Compra de esta su hacienda sobredicha un par de bueyes si los halla y en acabando de arar con ellos sus sementeras, por no andar cuidando todo al año de ellos, o antes que los maten otros lo mata el y quemando su arado los asa consumiéndolos ${ }^{33}$ (NUSDORFFER, 15/03/1738, f. $14 \mathrm{v})$.

Fossem eles de animais de tração ou de reprodução, os currais sob supervisão indígena não eram garantia de rendimento a longo prazo. Os espanhóis entendiam esta conduta nativa não apenas como traços de selvageria irreversivelmente persistentes no seu modo de ser, mas também como marcas de sua conduta. Este é o teor, por exemplo, da reclamação que o alcaide de Santa Fé, Don Gabriel de Lassaga, faz ao

predadores que apresentam elementos de desigualdade social, contrapondo-os aos grupos sul-ameríndios cultivadores que não demonstram tais disparidades.

${ }^{33}$ Información y certificación acerca de varios puntos pertenecientes a los indios guaraníes, mandadas hacer por el P. Jayme de Aguilar, provincial de las Provincias del Paraguay, Tucumán y Río de la Plata. Assinado pelo padre Bernardo Nusdorffer, Santa Candelaria, 15 de marzo de 1738. 
DOSSIÊ: FONTES E PROBLEMAS COLONIAIS, LEITURAS E ANÁLISES ATUAIS: TEMAS DA CULTURA SUL-AMERÍNDIA NO CONTEXTO COLONIAL

governador do Rio da Prata, anunciando que os bens disponíveis na redução de São Xavier "son casi ningunos, porque el ganado vacuno que tuvo en tiempo, en número de dieciséis a veinte mil cabezas, se alzo por la indolencia natural de los Indios34" (LASSAGA, 1785, f. 1v). Se o povoado passava fome, era por causa da incapacidade dos índios em manter os animais em cativeiro, fazendo-se perder todo um rebanho por descuido ou em banquetes despreocupados com o dia seguinte.

$\mathrm{Na}$ mesma correspondência, Lassaga informa que o governador Don Juan José de Vértiz doou, em 1780, três mil cabeças de gado à redução de São Pedro com a condição que os animais ficassem

a Cargo de un capataz Español y peones que se pagan con el producto de los cueros del consumo de reses: cuyo arbitrio fue preciso a fin de que los indios no destruyesen el ganado y con esta reserva tenga la subsistencia que no tendría si estuviera en el todo a cargo de los mismos indios (LASSAGA, 1785, f. 3v).

Ao que parece, a domesticação de animais não foi uma prática usual nas economias tradicionais sul-ameríndias, bem como não satisfatória sua introdução nos meios produtivos pós-contato. Porém, isto não se deveu à incapacidade de incorporar tal técnica ou à imprevidência com relação ao trabalho e à produção. Equivocado também seria entender que os animais possuíam unicamente a função de servir como alimento para os sul-ameríndios, sendo relegados a uma posição de meros fornecedores proteicos. A ontologia nativa possuía um entendimento mais complexo sobre os animais e as relações que eram estabelecidas com eles. O que distanciava os sul-ameríndios da domesticação de animais não era o resultado de uma "escolha consciente", mas o efeito de uma impossibilidade de "transformar profundamente seu modelo de relação com o animal selvagem e, mais geralmente, com a natureza" (DESCOLA, 2002, p. 107).

Segundo a teoria do perspectivismo 35 , a cosmologia indígena identifica nos demais seres (desde os animais, passando por plantas até

\footnotetext{
${ }^{34}$ Informe do alcaide Don Gabriel de Lassaga ao governador intendente de Buenos Aires, Francisco de Paula Sanz. Santa Fe, 06 de outubro de 1785.

${ }^{35}$ Cf. Viveiros de Castro (2002a), capítulo 7.
} 

TEMAS DA CULTURA SUL-AMERÍNDIA NO CONTEXTO COLONIAL

astros celestiais) a capacidade de manter um ponto de vista; isto porque, em uma instância primeira do ser, todos compartilham da mesma origem substancial: a humanidade. Dito de outra forma, nesta concepção, macacos, onças, peixes, árvores, a lua, todos possuem uma semelhança interna - uma alma humana - revestida por uma carapaça corporal que os diferencia. Daí que "os animais vêem da mesma forma que nós coisas diversas do que vemos porque seus corpos são diferentes dos nossos" (VIVEIROS DE CASTRO, 2002a, p. 380, grifos do autor) ${ }^{36}$. A ideia parte da concepção animista de que originalmente todos os seres eram humanos e, por causa de eventos cataclísmicos, foram adquirindo suas formas atuais em um processo de metamorfose, ou como salientou Susnik, "en su origen fueron antropomorfos y se volvieron zoomorfos" (1985, p. 42).

Assim ocorre, por exemplo, com os Mocovi, que explicam por meio de seus mitos a criação de alguns animais. Dizem eles que, certa vez, o sol despencou e incendiou toda a terra, consumindo árvores, plantas, animais e homens. Alguns Mocovi, para fugir das chamas, refugiaram-se nos rios e lagos, transformando-se em capivaras e jacarés. Outros dois, um marido e sua mulher, subiram em uma altíssima árvore onde podiam ver o incêndio. Uma chama atingiu os dois, chamuscando-os na cara e transformou ambos em macacos (GUEVARA, [1764] 1836, p. 35). Já, para um subgrupo Guarani, "las aves acuáticas sufrieron su zoomorfización por haber - como seres primigenios - abusado de la pesca" (SUSNIK, 1985, p. 45)37. Aos Pampa cabia um tabu alimentar:

\footnotetext{
${ }^{36}$ Este "ver da mesma forma coisas diversas" advém do conceito de multinaturalismo, entendido como a inversão ontológica do multiculturalismo moderno. Neste último, prefigura-se a existência de um mundo pronto e original alvejado por uma variedade de pontos de vista, todos partindo de seu entendimento sobre o funcionamento da realidade. Desta forma, compreende-se que cada grupo humano dispõe de sua visão de mundo peculiar, e que todas são relativas a uma verdade preexistente. Já para a cosmologia ameríndia, se todos os seres compartilham da mesma essência (humanidade) - e por isso todos são um ponto de vista -, é a cultura (a humana) que é una e universal; a natureza, ou seja, o mundo que se vê, é que é diversificado e múltiplo: "não há pontos de vista sobre as coisas - as coisas e os seres é que são pontos de vista"; “a questão aqui, portanto, não é saber 'como as macacos vêem o mundo' [...], mas que mundo se exprime através dos macacos, de que mundo eles são o ponto de vista" (VIVEIROS DE CASTRO, 2002a, p. 385).

${ }^{37}$ A essência humana parecia estender-se para além dos animais: os Mocobi referiam-se ao sol como uma mulher (GUEVARA, [1764] 1836, p. 34), e uma parcialidade guarani identifica nas árvores uma alma dócil ou uma indócil (CADOGAN, 1950, p. 331).
} 
se alimentan ellos de la carne de potros, de avestruces, y de liebres, muy abundantes en aquellas tierras; y, aunque abundes en estos campos también los puercos, no los tocan, porque creen que habían sido hombres (CA, 1735-1743, p. 581).

A origem mítica dos porcos denota não apenas uma filosofia peculiar e específica dos nativos, como uma forma de relacionamento com os seres que está para além da dicotomia humanos/não humanos: "dizer que os pecaris são humanos não nos 'diz' nada sobre os pecaris, mas muito sobre os humanos que o dizem" (VIVEIROS DE CASTRO, 2002b, p. 133, grifo do autor).

O perspectivismo e o animismo advertem os índios de que eles não fazem parte de uma espécie superior às demais, pois se todos os animais possuem uma subjetividade, "a despeito das aparências enganadoras, eles não vivem em um plano ontológico distinto daquele dos humanos" (DESCOLA, 1998, p. 29); ou como bem colocou Susnik, "Ios animales no son para los indígenas solamente 'animales': el mundo zoomorfo implica siempre, la proyección anímica del hombre" (SUSNIK, 1985, p. 47). Daí que a domesticação não era uma prática naturalmente assimilável aos meios socioeconômicos sul-ameríndios. Porém, a interdição da domesticação não impediu de modo algum o amansamento e adoção de animais, pois justamente o que diferencia a domesticação do amansamento é o grau de afinização que se estabelece com os outros seres. A sujeição em cativeiro pré-figura uma relação de tutela impraticável nesta cosmologia que percebe os animais não só como iguais, mas também como portadores de uma subjetividade importante para a manutenção da sociabilidade. A domesticação viria a interromper qualquer possibilidade de uma relação justa e reparatória, levando-se em conta que "as relações entre os dois mundos são governadas por uma lógica de troca na qual os participantes são de direito, senão de fato, equivalentes" (DESCOLA, 2002, p. 106). Por isso, a caça é semelhante à guerra, em que o adversário é detentor de uma subjetividade igual a do caçador - "toda morte é a morte de uma pessoa" (VIVEIROS DE CASTRO, 2006, p. 115) -, obrigando este a 
DOSSIÊ: FONTES E PROBLEMAS COLONIAIS, LEITURAS E ANÁLISES ATUAIS: TEMAS DA CULTURA SUL-AMERÍNDIA NO CONTEXTO COLONIAL

garantir "o renascimento de suas presas mediante o respeito ritual por seus restos mortais" (SAHLINS, 2004, p. 481). Com efeito, a posição de quem é a caça ou o caçador é tão incerta quanto quem é o inimigo ou o herói em uma guerra: tudo depende de qual ponto de vista está no controle. A domesticação anularia uma subjetividade que de maneira alguma pode ser menosprezada.

Para os espanhóis, a aquisição de novas técnicas correspondia ao encaminhamento do processo civilizatório: era o que ditava o grau de evolução capacitativa que a sociedade possuía e a distinguia das demais. Para os índios, a aquisição de novas técnicas estava relacionada à possibilidade de realocação do tempo: o aprimoramento produtivo, por exemplo, não rendia excedentes, mas permitia que se alcançasse o nível desejado de sustento necessário de forma mais eficaz, possibilitando o reajuste do tempo para as coisas ligadas à sociabilidade. As inovações técnicas introduzidas no sistema produtivo indígena não eram assimiladas como distintivo civilizatório ou qualificação social; o que realmente fazia a diferença era a capacidade de poder manter as relações socioeconômicas através das prestações e contraprestações. A unidade social estaria assegurada enquanto houvesse aliados com quem trocar e inimigos com quem guerrear. Caso uma nova técnica ou tecnologia pudesse vir a defasar de alguma forma a sociabilidade ontológica nativa, a própria ordem social trataria de incapacitá-la.

A escravidão, aparentemente, foi uma prática que não penetrou nas relações socioeconômicas sul-ameríndias, apesar do constante emprego destes indígenas como força de trabalho servil nas relações produtivas coloniais. A relação que os nativos mantinham com os cativos de guerra, como já comentado anteriormente, não se resumia à morte e manducação do sujeito, ou à sua utilização como bem de troca. Muitos inimigos apresados eram incorporados ao cativeiro de maneira a integrarem-se como membros efetivos do grupo.

Martín Dobrizhoffer relata um acordo firmado entre agentes administrativos e os índios Abipone quando da fundação de São Jerônimo, que abrigaria estes nativos, em 1748. O trato previa que tanto 
DOSSIÊ: FONTES E PROBLEMAS COLONIAIS, LEITURAS E ANÁLISES ATUAIS: TEMAS DA CULTURA SUL-AMERÍNDIA NO CONTEXTO COLONIAL

os colonos espanhóis quanto os índios Abipone dariam liberdade aos inimigos aprisionados 38 :

A los pactos se agregó la cláusula de que se concedería a los abipones y mocobíes cautivos de los españoles amplia libertad de volver a los suyos. Para que el precio de la libertad fuera íntegro, también los cristianos cautivos de los abipones debían ir donde quisieran. Así muchos volvieron a Córdoba, a Asunción o a Corrientes, rescatados por medio de espadas, frenos, sombreros, vestidos de lana o bolas de vidrio. No pocos de los cautivos, tanto españoles como negros o guaraníes no quisieron de ningún modo volver al suelo patrio, ya que acostumbrados a vivir entre los abipones, consideraron que perderían la libertad de que gozaban estando en su servidumbre (DOBRIZHOFFER, [1783-1784] 1967-1970, v. 3, p. 129).

Destaca-se no trecho supracitado a menção feita à existência de cativos convivendo entre seus raptores. Parece que a vida que levavam junto aos Abipone era melhor do que aquela que desfrutavam em liberdade, não existindo qualquer semelhança com o regime de escravidão ou de trabalho forçado. A não incorporação da mão de obra servil nas relações produtivas nativas prova que a escravidão não é a mera expressão cultural de uma determinada sociedade em uma determinada época. Ela revela antes uma possibilidade ontológica do que uma adaptabilidade histórica. Se os índios não escravizavam os seus cativos de guerra, não é porque suas bases econômicas não suportassem tal recurso, ou porque lhes faltasse alcançar algum suposto estágio civilizatório. Os sul-ameríndios não praticavam a escravidão pelo mesmo motivo que não domesticavam os animais: a impossibilidade de conceber a propriedade sobre um "outro", cuja perspectiva é fundamental às relações ontológicas. E se esta perspectiva "outra" é tão fundamental, não deve causar estranheza o fato de que o oposto ontológico à escravidão é a afinização. Daí que um inimigo apresado em uma investida bélica podia se tornar um parente: "acaban cruelmente con todos; menos con la tierna edad, a la cual educan a su

${ }^{38}$ Cf. Paz (2009, p. 105). 
DOSSIÊ: FONTES E PROBLEMAS COLONIAIS, LEITURAS E ANÁLISES ATUAIS: TEMAS DA CULTURA SUL-AMERÍNDIA NO CONTEXTO COLONIAL

manera, y con las mujeres más parecidas y jóvenes, a las cuales conservan para servirse de ellas en su inmoralidad" (CA, 1730-1735, p. 4). Assim era também entre os Guaicuru, que em seus assaltos matavam a todos, "excepto los muchachos que reservan para criarlos conforme a sus costumbres y aumentar así su nación casándolos con sus hijas" (LOZANO, 1733, § IX, f. 67).

A incorporação do inimigo no interior do grupo era realizada por meio de diversos mecanismos simbólico-rituais, num processo de aproximação cognática. O "outro" (o inimigo) tornava-se um integrante do grupo, nos termos daqueles que o cativaram. Isto porque a estruturação da ordem parental, para os sul-ameríndios, estava fundamentada na afinização, e, por isso, na construção da pessoa como membro familiar do grupo. Diferente da ordem ocidental, que assegurava na sucessão consanguínea a formalização do parentesco, aos índios era necessário produzir esta relação. Entende-se aí, em parte, as modificações corporais realizadas tanto nos adultos como nas crianças, já que a marca de pertencimento a um grupo familiar está naquilo que assemelha os corpos entre os parentes. Exemplo disto é o que ocorreu a um indiozinho de dez anos raptado pelos Paiaguá, que, após conseguir fugir de seu cativeiro, fala a um jesuíta que "el motivo de su huida era el miedo de que le perforasen su labio inferior y las orejas, como ellos acostumbran hacer con los suyos" (CA, 1735-1743, p. 417418); ou no caso relatado por Martín Dobrizhoffer ([1783-1784] 19671970 , v. 3, p. 193) sobre um espanhol batizado com o nome de Cristóbal Almaraz e que, raptado quando criança pelos Abipone, foi criado à "usança nativa". O jesuíta descreve que, quando adulto, já falava, agia e tinha o rosto marcado como costumavam fazer os Abipone, além de ser casado com a filha de um cacique. A modificação corporal, para além das questões estéticas, gerava mudanças substanciais no ser identitário, transformando a pessoa e possibilitando a sua interiorização no seio familiar: é "preciso afinizar para incorporar, e é preciso incorporar para consangüinizar" (VIVEIROS DE CASTRO, 2002a, p. 167). 
DOSSIÊ: FONTES E PROBLEMAS COLONIAIS, LEITURAS E ANÁLISES ATUAIS: TEMAS DA CULTURA SUL-AMERÍNDIA NO CONTEXTO COLONIAL

Para o sistema ontológico indígena, as perspectivas outras compunham um quadro em que seria inimaginável um estado solipsista ausente de relações sociais. Os "outros" eram fundamentais para a existência do coletivo, ou porque carregavam em si uma subjetividade necessária à manutenção e reprodução do grupo local (seja pela incorporação literal das substâncias ou pela afinização no corpo familiar), ou porque proporcionavam recursos materiais utilizados para a produção de socialidade (seja por meio das guerras, ou por meio das bebedeiras e de convites festivos). Frente às perspectivas que sustentavam as relações entre os seres, o isolamento provocaria a asfixia sociológica do grupo - em contrapartida, a total abertura poderia desvirtuar normas cosmológicas. O equilíbrio era a meta a ser alcançada, por meio das incorporações, que dinamizavam as relações sociais; e das interdições, que mantinham a coesão ontológica tradicional. O fundamental, no final das contas, era não permanecer fechado: "a continuidade das culturas indígenas consiste nos modos específicos pelos quais elas se transformam" (SAHLINS, 1997, p. 126).

O que pretendi demonstrar com este trabalho é que, em primeiro lugar, o contato não foi mantido, ao longo do século XVIII, por uma iniciativa unilateral dos agentes coloniais; tanto estes como os grupos indígenas possuíam interesses em manter relações entre si, quer fossem elas trocas comerciais ou então ligadas à formação de alianças militares. Devido a isto, a atuação ativa e deliberada dos índios aparentou ser, na percepção dos espanhóis, inconstante no modo de agir. Suas ações, que oscilavam entre aproximações colaboracionistas e retrações hostis, surpreendiam os agentes coloniais. Além da desconfiança que geravam as decisões indígenas, os colonos e missionários direcionavam duras críticas aos costumes nativos relacionados aos rituais festivos, como as bebedeiras e a antropofagia; à economia autóctone, principalmenteem relação à ausência de excedente produtivo; ao regime de prodigalidade 
DOSSIÊ: FONTES E PROBLEMAS COLONIAIS, LEITURAS E ANÁLISES ATUAIS: TEMAS DA CULTURA SUL-AMERÍNDIA NO CONTEXTO COLONIAL

e ao uso de instrumentos rudimentares. E, ao contrário do que supunham muitos cronistas da época, estas práticas indígenas não eram o resultado da incapacidade técnica ou própria do caráter supersticioso de povos desprovidos de ídolos. Eram, na verdade, resultantes de uma cosmologia que dava sustentação ao sistema sociológico nativo. Daí que, por exemplo, a guerra - e todos rituais que a antecediam e/ou que caracterizavam o seu processo - era realizada com o intuito de captar recursos simbólicos e materiais que garantiriam a manutenção da sociabilidade do grupo; ou, então, a economia de consumo imediato, que não gerava nem excedentes, nem um sistema de armazenamento, revelando uma compreensão específica do que é a natureza e de como se relacionar com ela.

Se, no século XVIII, algumas atitudes ou práticas indígenas ainda pareciam estranhas e eram tidas como inconsequentes aos olhos ocidentais é porque mantinha-se, a despeito das estratégias catequéticas e metropolitanas, o choque inaugural entre dois mundos tão distintos. Tratava-se, na verdade, de duas cosmologias que buscavam comunicar-se para poderem conviver; e que, em determinados momentos, até puderam complementar-se, mas que se mostraram, em geral, distintas e incompatíveis, como procurei demonstrar neste artigo.

\section{Referências bibliográficas}

ANÔNIMO. Relación compendiosa de los servicios que han hecho a su Majestad los Indios de las doctrinas que están a cargo de los padres de la Compañía de Jesús en esta Provincia del Paraguay de Nación Guaranís, o como los llaman vulgarmente tapes, desde el año 1637 hasta octubre del presente 1735, así en el distrito del gobierno de Buenos Aires, como en el del Paraguay. AGN (Archivo General de la Nación, Buenos Aires) IX 6-9-7. out. 1735.

Extracto sobre la nueva reducción y población de los indios infieles de la nación Pampa. 11 de agosto de 1741. BME (Biblioteca do Museo Etnográfico, Buenos Aires) Carpeta I, I.8. 11 ago. 1741.

BENAVIDES, Miguel. Carta do Padre Miguel de Benavides. São Miguel, 2 de junho de 1730. AGN (Archivo General de la Nación, Buenos Aires) IX 4-1-1. 02 jun. 1730. 
DOSSIÊ: FONTES E PROBLEMAS COLONIAIS, LEITURAS E ANÁLISES ATUAIS: TEMAS DA CULTURA SUL-AMERÍNDIA NO CONTEXTO COLONIAL

. Carta do cacique Don Miguel Gerónimo Benavides ao Vice-rei Don Juan José de Vértiz y Salcedo. São Jerônimo, cerca de 1780. AGN (Archivo General de la Nación, Buenos Aires) IX 4-1-6. c. 1780.

CA. Cartas anuas de la Provincia del Paraguay, año 1730-1735. São Leopoldo: Instituto Anchietano de Pesquisa/UNISINOS, 1994a. (transcrição de Carlos Leonhradt, S. J. 1928).

Cartas anuas de la Provincia del Paraguay, año 1735-1743. São Leopoldo: Instituto Anchietano de Pesquisa/UNISINOS, 1994b. (transcrição de Carlos Leonhradt, S. J, 1928).

CABILDO DE SÃO INÁCIO. Carta do cabildo de São Inácio Guazú ao administrador geral das missões, Don Juan Angel de Lazcano. San Ignácio, 13/06/1774. MM (Museo Mitre, Buenos Aires) Arm. B, c. 21, n. 12.13 jun. 1774.

CADOGAN, León. El culto al Arbol y a los Animales Sagrados en el Folklore y las Tradiciones Guaraníes. América Indígena, Cidade do México, v. 10, n. 4, p. 327-333, 1950.

CATAFESTO DE SOUZA, José Otávio. O sistema econômico nas sociedades indígenas Guarani pré-coloniais. Horizontes Antropológicos, Porto Alegre, v.8, n.18, p. 211-253, 2002.

CÉDUla REAL. Cédula Real ao Padre Superior das Missões de Chiquitos. 06 de julho de 1727. MM (Museo Mitre, Buenos Aires) Arm. B, c. 17, n. 50. 06 jul. 1727.

CONSELHO DAS ÍNDIAS. Carta do Conselho das Índias ao Rei da Espanha. 12 de maio de 1684. BME (Biblioteca do Museo Etnográfico, Buenos Aires) Carpeta G, G.19. 12 mai. 1684.

DESCOLA, Philippe. Estrutura ou sentimento: a relação com o animal na Amazônia. Mana, Rio de Janeiro, v. 4, n. 1, p. 23-45, 1998.

Genealogia de objetos e antropologia da objetivação. Horizontes Antropológicos, Porto Alegre, v. 8, n. 18, p. 93-112, 2002.

DOBLAS, Gonzalo de. Memoria histórica, geográfica, política y económica sobre la provincia de Misiones de indios guaranís. In: PEDRO DE ANGELIS. Colección de Obras y Documentos Relativos a la Historia Antigua y Moderna de las Provincias del Río de la Plata. Buenos Aires: Imprenta del Estado, [1785] 1836. Tomo 3.

DOBRIZHOFFER, Martín S. J. Historia de los Abipones. Resistencia: Universidad Nacional del Nordeste, [1783-1784] 1967-1970. 3 v. 
DOSSIÊ: FONTES E PROBLEMAS COLONIAIS, LEITURAS E ANÁLISES ATUAIS: TEMAS DA CULTURA SUL-AMERÍNDIA NO CONTEXTO COLONIAL

FAUSTO, Carlos. Da inimizade: forma e simbolismo da Guerra Indígena". In: NOVAES, Adauto (Org.). A Outra Margem do Ocidente. São Paulo: Companhia das Letras, 1999. p. 251-282.

GORDON, Flávio. Nossos aipins são melhores do que os outros. Revista Habitus, Rio de Janeiro, v. 1, n. 1. p. 15-32, mar. 2003. Disponível em: http://www.ifcs.ufrj.br/ habitus/pdf/1gordon.pdf . Acesso em: 14 abr. 2009.

' 'O sexo dos caracóis': sugestões para uma antropologia reversa, disparativa e contra o Estado. 2006. Disponível em: http://nansi.abaetenet.net/abaetextos . Acesso em: 14 jun. 2010.

GUEVARA, Pedro. Historia del Paraguay, Río de la Plata y Tucumán. In: PEDRO DE ANGELIS. Colección de Obras y Documentos Relativos a la Historia Antigua y Moderna de las Provincias del Río de la Plata. Buenos Aires: Imprenta del Estado, [1764] 1836. Tomo 2.

HERRERA, José. Carta do governador do Rio da Prata Don José de Herrera ao Rei da Espanha. Buenos Aires, 05 de dezembro de 1686. BME (Biblioteca do Museo Etnográfico, Buenos Aires) Carpeta G, G.29. 05 dez. 1686.

IMBERT, Antonio A. Carta do Bispo de Buenos Aires, Antonio Azcona e Imbert ao governador do Rio da Prata Don Andrés de Robles. Buenos Aires, 11 de fevereiro de 1678. BME (Biblioteca do Museo Etnográfico, Buenos Aires) Carpeta F, F.4. 11 fev. 1678.

Carta do Bispo de Buenos Aires, Antonio Azcona e Imbert, ao Rei Carlos II. Buenos Aires, 09 de janeiro de 1683. BME (Biblioteca do Museo Etnográfico, Buenos Aires) Carpeta G, G.13. 09 jan. 1683.

KERN, Arno Alvarez. O processo histórico platino no século XVII: da aldeia guarani ao povoamento missioneiro. Estudos Ibero-Americanos, Porto Alegre, v. 11, n. 1, p. 23 $41,1985$.

LASSAGA, Gabriel. Informe do alcaide Don Gabriel de Lassaga ao governador intendente de Buenos Aires Francisco de Paula Sanz. Santa Fe, 06 de outubro de 1785. AGN (Archivo General de la Nación, Buenos Aires) IX 4-1-6. 06 out. 1785.

LATOUR, Bruno. Jamais Fomos Modernos. Rio de Janeiro: Ed. 34, 1994.

LOZANO, Pedro. Descripción chorographica de Terreno Ríos, Arboles, y Animales de los dilatadísimas provincias del Gran Chaco, Gualamba, y de los Ritos y Costumbres de la innumerables naciones de barbaros e infieles que le habitan. Córdoba: Colegio de Asunción, 1733. 

TEMAS DA CULTURA SUL-AMERÍNDIA NO CONTEXTO COLONIAL

NUSDORFFER, Bernardo. Información y certificación acerca de varios puntos pertenecientes a los indios guaraníes, mandadas hacer por el P. Jayme de Aguilar, provincial de las Provincias del Paraguay, Tucumán y Río de la Plata. Assinado pelo padre Bernardo Nusdorffer. Santa Candelaria, 15 de marzo de 1738. MM (Museo Mitre, Buenos Aires) Arm. B, c. 18, n. 3. 15 mar. 1738.

PALERMO, Miguel Ángel. A través de la frontera. Economía y sociedad indígenas desde el tiempo colonial hasta el siglo XIX. In: TARRAGÓ, Myriam (Org.). Nueva Historia Argentina: los pueblos originarios y la conquista de América, tomo I. Buenos Aires: Sudamericana, 2000. p. 343-382.

PAZ, Carlos D. La “nación” de los abipones: un experimento político exitoso? 2009. 325 f. Tese (Doutorado em História) - Universidad Nacional del Centro de la Provincia de Buenos Aires, [2009].

ROBLES, Andrés de. Carta do governador do Rio da Prata Andrés de Robles ao Rei Carlos II. Buenos Aires, 24 de maio de 1678. BME (Biblioteca do Museo Etnográfico, Buenos Aires) Carpeta F, F.6. 24 mai. 1678.

ROZAS, Domingo O. Bando do governador do Rio da Prata Domingo Ortiz Rozas. Buenos Aires, 27 de outubro de 1742. AGN (Archivo General de la Nación, Buenos Aires) IX 8-10-1. 27 out. 1742.

SAHLINS, Marshall. O 'pessimismo sentimental' e a experiência etnográfica: por que a cultura não é um "objeto" em via de extinção (parte II). Mana, Rio de Janeiro, v. 3, n. 2, p. 103-150, 1997.

Edusp, 2001.

Como Pensam os "Nativos": sobre o capitão Cook, por exemplo. São Paulo: . Cultura na Prática. Rio de Janeiro: Ed. UFRJ, 2004.

SUSNIK, Branislava. Los aborígenes del Paraguay VI: Aproximación a las creencias de los indígenas. Asunción: Museo Etnográfico "Andrés Barbero", 1985.

TATA, Luis. Carta do corregedor do cabildo de Santiago, Don Luis Tata, ao governador do Rio da Prata Pedro de Ceballos. Santiago, 26 de fevereiro de 1758. MM (Museo Mitre, Buenos Aires) Arm. B, c. 18, n. 23.26 fev. 1758.

VIVEIROS DE CASTRO, Eduardo. A Inconstância da Alma Selvagem: e outros ensaios de antropologia. São Paulo: Cosac Naify, 2002a.

. O nativo relativo. Mana, Rio de Janeiro, v. 8, n. 1, p. 113-148, 2002 b. 
DOSSIÊ: FONTES E PROBLEMAS COLONIAIS, LEITURAS E ANÁLISES ATUAIS: TEMAS DA CULTURA SUL-AMERÍNDIA NO CONTEXTO COLONIAL

Caçadores e pastores: entrevist". In: CHACON, Alex Peirano (Org.). Por Ti América: aventura arqueológica. Rio de Janeiro: Centro Cultural Banco do Brasil. 2006. [original em CD ROM].

Entrevista. In: SAVAZONI, Rodrigo; COHN, Sergio (Orgs.). Cultura Digital.br. Rio de Janeiro: Beco do Azougue, 2009. p. 78-95. Disponível em: http://www.cultura.gov.br/site/wp-content/uploads/2009/09/cultura-digital-br.pdf Acesso em: 16 mai. 2011.

WILDE, Guillermo. "Poderes del ritual y rituales del poder: un análisis de las celebraciones en los pueblos jesuíticos de guaraníes". Revista Española de Antropología Americana, Madrid, n. 33, p. 203-229. 2003.

ZAVALA, Francisco B. Carta de Francisco Bruno de Zavala ao governador do Rio da Prata, Don Francisco de Bucarelli. Yapeyu, 9 de fevereiro de 1769. AGN (Archivo General de la Nación, Buenos Aires) IX 18-5-1. 09 fev. 1769. 